\title{
INFLUENCE OF INNOVATIVE BUSINESSES ON CONSUMER PREFERENCES: A STUDY ON LAPTOP USERS
}

\section{DOI: 10.17261/Pressacademia.2015211612}

\author{
Ahmet Uyar', Kubra Kılıcaslan ${ }^{2}$ \\ 1Afyon Kocatepe University. ahmetuyar@aku.edu.tr \\ ${ }^{2}$ Afyon Kocatepe University. kkilicaslan@aku.edu.tr
}

\section{Keywords}

Innovation, innovative business, consumer behavior.

\begin{abstract}
Globalization raises new difficulties for businesses in terms of competition. Those businesses which operate in the global scale have increased the rate of competition. Competitors of acompany is not just those within its own national boundaries anymore but others which are established in another part of the world and getting a big market share. As globalization promotes competition, businesses become more enthusiastic about getting one step ahead of their competitors by innovation. Innovative businesses turn towards new, marketable and distinguishing products to influence consumers. Consumers meet a different technology each day and their expectations increase. Those businesses which are not innovative have no chance for competition anymore. From this perspective, innovation is vital for businesses. This study aimed to find out to what extent laptop computer users paid attention to innovation when buying products. The study was based on questions like "Do consumers, when they buy products, care about whether the relevant companies are innovative?" and "How much important is innovation when compared with marketing activities?" A questionnaire was administered to laptop computer users in this regard. The results suggest that all segments of the society pay attention to innovation, that they lean towards innovation when buying products, and that innovative businesses always tend to be preferred.
\end{abstract}

\section{YENILIKÇi IŞLETMELERIN TÜKETICI TERCIHLERI ÜZERINDEKI ETKISI: DIZÜSTÜ BILGISAYAR KULLANICILARI ÜZERINE BIR ARAŞTIRMA}

\section{Anahtar Kelimeler}

Yenilik, Yenilikçi İşletme, Tüketici Davranışı

JEL Sınıflandırması O31,M14, M19

\section{ÖZET}

Küreselleşme işletmelere rekabet açısından yeni zorluklar çıkarmaktadır. Global ölçekte faaliyet gösteren işletmeler rekabetin ölçeğini büyütmüştür. Bir işletmenin rakibi artık yalnızca kendi ulusal sınırları içerisindeki firmalar değil dünyanın bir ucunda kurulmuş ve büyük bir pazar yakalamış diğer işletmelerdir. Küreselleşme rekabeti arttırdıkça işletmelerin yenilik yaparak rakiplerinden bir adım daha önde olma isteklilikleri de gelişmektedir. Yenilikçi işletmeler tüketicileri etkileyecek yeni, pazarlanabilir ve fark yaratan ürünlere yönelmektedir. Tüketiciler her geçen gün farklı bir teknolojiyle tanışmakta, beklentileri artmaktadır. Yenilikçi olmayan işletmelerin rekabet edebilme şansları kalmamıştır. Bu açıdan işletmeler için yenilik hayati bir öneme sahip olmaktadır. Bu çalışmada dizüstü bilgisayar kullanıılarının ürün satın alırken yenilikçiliğe ne kadar dikkat ettikleri araştırılmaktadır. Tüketiciler ürün satın alırken firmaların yenilikçi olup olmamasına dikkat etmekte midir? pazarlama faaliyetleriyle karşılaştırıldığında yeniliğin önemi ne kadardır? gibi sorular çalışmanın ana eksenini oluşturmaktadır. Bu amaçla dizüstü bilgisayar kullanıcılarına üzerine bir anket uygulanmıştır. Çıkan sonuçlara göre yeniliğin toplumun tüm kesimleri tarafından önemsendiği, ürün alırken yeniliğe dikkat edildiği, yenilikçi işletmelerin her zaman bir tercih sebebi olabileceği bulgularına ulaşılmıştır. 


\section{GiRiş}

Günümüz pazar şartlarında sadece maliyet açısından rekabet artık yeterli olmamaktadır.Gelişen teknoloji, artan rekabet; ürün ve hizmette kalite, müşteri istek ve ihtiyaçlarına hızı cevap verebilme ve ürün yaşam ömürlerinin kısalması sonucu yeniliğin gerekliliği bir kez daha ön plana çıkmaya başlamıştır. Müşteri istek ve ihtiyaçlarına cevap verebilmek kadar müşteri isteklerinin çok hızlı değiştiğini ve yeni ürünlerin ardı arkasına piyasaya çıktıkları düşünülürse bilgi ve teknolojide değişim ivmesinin gücü rahatlıkla görülebilmektedir. Bir firmanın, tüm bu durumlara cevap verebilecek kapasitede olmasında izlemesi gereken başlıca yenilik stratejisi ise bu akımı bir kültür olarak organizasyon içine yaymaktan geçmektedir.Toplam kalite yönetimi esasları çerçevesinde yenilik yapabilme ve her şeyden önce tek seferlik yeniliğin yetersiz olduğu bilinci ile sürdürülebilir dinamik bir yapıda yenilik felsefesini benimseme, yenilik stratejisi için olmazsa olmaz şartlardandır.Rekabet ve kalkınmanın anahtarı üretken olabilmektir. Üretkenliğin anahtarı ise yeniliktir .Yenilik, bu noktada her şeyden önce bir işletmenin varlığını sürdürebilmesindeki önemli bir etken haline gelmiştir.Yeniliğe adapte olamayan veya yenilik yapamayan işletmeler pazarda rekabet edemez duruma gelmişlerdir (Çubukçu, 2011: 6).Yenilikçi işletmeler, yenilikleri gelişmenin vazgeçilmez nedenleri biçiminde algılayan ve uygulayan işletmelerdir.Yenilik, işletmelerin rakipleri karşısında üstünlük kazanmak, başarıya ulaşmak ve etkili olmak için her türlü fırsatı değerlendirmek, hatta fırsat yaratmak için kaçınılmaz olmaktadır (Budak 1998:26).Yenilik bir disiplin olarak sunma, öğrenme ve uygulama yeteneğidir. Bu yüzden, girişimciler için de özel bir araçtır (Drucker 1993:20). Araştırmalar, yeniliklerin girişimlerin gelişmesini uyarıcı etki yaptığı ve rekabet avantajının temel bir kaynağı olduğunu göstermektedir (Sarıçay, 2013: 35).

\section{LITERATÜR TARAMASI}

\subsection{Yenilik Kavramı}

Oslo Kılavuzu'na göre yenilik (İnovasyon); “işletme içi uygulamalarda, işyeri organizasyonunda veya dış ilişkilerde yeni veya önemli derecede iyileştirilmiş bir ürün (mal veya hizmet), bir süreç veya yeni bir pazarlama yöntemi ya da yeni bir organizasyonel yöntemin gerçekleştirilmesi olarak görülmektedir. Yenilik, yaratıcı bir fikri katma değer oluşturabilir ve pazarlanabilir bir ürüne dönüştürme süreci olarak ele alınmaktadır. Yani yenilik, bir icadın ötesinde "yeni bir iş fırsatı" oluşturmaktadır (Gökçe, 2010: 1 ).Yenilikle (İnovasyon) ilgili geçmişten günümüze kadar birçok tanımlama yapılmıştır. Yeniliğin ilk tanımlarından biri Schmookler (1966) tarafından yapılmıştır ve bu tanıma göre bir ürün ya da hizmet geliştirmek için yeni bir yöntem ya da girdi kullanan şirketler bir değişiklik yapmış olur ve değişikliği ilk yapan işletmeler, yaptığı bu hareket yenilik (inovasyon) olarak nitelendirilir (Akt.Çeliktaş, 2008). Daha sonraları, Freeman (1982) yenilik kavramı "Endüstriyel Yenilik" olarak adlandırılarak farklı bir görüş ileri sürmüştür. Freema'a göre endüstriyel yenilik, yeni/iyileştirilmiş bir ürünün pazarlanması veya yeni/iyileştirilmiş bir sürecin ya da ekipmanın ilk defa ticari kullanım için yürütülen tasarım, üretim, yönetim ve ticari faaliyetleri kapsayan bir süreç olarak görülmektedir (1982'den Akt. Çeliktaş, 2008).Porter a göre (1990) yenilik, rekabet avantajı bağlamında açıklamıştır. Diğer bir değişle "şirketler, yenilik ile rekabet avantajı yakalamaktadır" (Ayyıldız, 2012 : 16). 
Günümüzde pek çok sektör için yenilik, rekabetin en önemli itici güçlerinden biri olarak kabul edilmektedir. Söz konusu sektörlerde işletmeler, performans kriteri olarak cirolarının ne kadarlık bir kısmını son beş yıl içerisinde geliştirdikleri ürünlerden elde ettiklerini göz önünde bulundurmaktadırlar. Tıbbi ürünler sektöründe lider konumda olan işletmelerden biri olan Baxter 2002 yılında elde etmiş olduğu cironun \%37'lik kısmını son beş yıl içerisinde geliştirmiş olduğu ürünlerden elde etmiştir. $3 \mathrm{M}$ gibi işletmelerde ise bu oran son yıllarda \%45'lere ulaşmıştır (Demirci vd. $2011: 3$ ).

İşletmeler sürekli değişen şartlar altında rekabetçi olabilmek ve küresel pazarlarda müşterilerin isteklerini karşılayabilmek için çeşitli yollar aramak zorunda kalmıştır (Özçiftci ve Sarıçay, 2014: 2). İşletmelerin küreselleşen dünyada rakiplerine karşı üstünlük sağlayabilmeleri için yeni ürün üretme ve yeni pazarlara girmede yeniliği bir rekabet aracı olarak kullanmaları zorunluluk haline gelmiştir.Yenilik yapmayan işletmelerin ise zaman içinde yok olmakları işletmeler için kaçınılmaz bir sonuç olacaktır (Öztürk, 2013: 98).Açıkça görülmektedir ki, mevcut koşullarda pazar lideri konumunda olan işletmeler, yenilikçi ürün ve hizmet geliştirebilme becerilerine sahip olan işletmelerdir. Havacılıktan kimyaya, otomotivden bilişime kadar hemen hemen bütün sektörlerdeki baskın konuma sahip olan işletmelerin yenilik yapabilme becerisine sahip olan işletmeler olduğu söylenebilir.Tablo 1.'de çeşitli sektörlerdeki pazar liderleri görülebilmektedir (Demirci vd. 2011: 4 ).

Tablo 1. Çeşitli Sektörlerde Pazar Liderleri

\begin{tabular}{|l|l|l|}
\hline Sektör & Pazar Liderleri & Yenilikçi Ürünleri \\
\hline Havacılık & Airbus, Boeing Yolcu uçağı & Yolcu uçağı \\
\hline Kimya & Pfizer, GlaxsoSmithKline & Ülser tedavi ilaçları \\
\hline Otomotiv & $\begin{array}{l}\text { Toyota, DaimlerChrysler, } \\
\text { Ford }\end{array}$ & $\begin{array}{l}\text { Otomobil tasarımı ve ilişkili } \\
\text { ürün geliştirme çabaları }\end{array}$ \\
\hline $\begin{array}{l}\text { Bilgisayarlar ve çipleri, donanım } \\
\text { Yazılım Geliştirme }\end{array}$ & Intel, IBM, Microsoft, SAP & $\begin{array}{l}\text { Bilgisayar } \\
\text { unsurları ve yazılım ünleri }\end{array}$ \\
\hline
\end{tabular}

Kaynak: Trott, 2005: 6

\subsection{Yenilik Türleri}

Yenilik türlerinin sınıflandırılması temelde birbirine benzemekle beraber, tamamen aynı değildir. Yeniliğin üç ana tipinin, örgütsel iş gelişimini desteklediği ifade edilmektedir (Karaca; 2009: 199).

\subsection{1. Ürün Yeniliği}

Ürün yeniliği, bir organizasyonun sahip olduğu ürün yelpazesindeki önemli değişiklikleri kapsar ve hem yeni mal ve hizmetler, hem de mevcut ürünlerde yapılan önemli değişiklikleri içine alır. Bu bakış açısıyla yeni ürünün yanında mevcut ürünlerinde üzerinde yapılan değişikliklerin ürün yeniliğini oluşturabileceği belirtilmektedir.Aynı bakış açısının devamı olarak, ürün yeniliği daha önce pazarda yer almayan "yeni veya geliştirilmiş ürünler" olarak nitelendirilmiştir.İşletmelerin bu şekilde, ürününü pazara sunarak ürün yeniliği yaptığından söz edilebilir.Yukarıdaki tanımlarda kısmen de görülebileceği üzere, bazı yönlerden ürün yeniliği, icat ile yakından ilişkili gibi gözükebilir. 
Mesela, bilişim teknolojisi ve buna bağlı olarak bilgisayarların kullanımından kaynaklanan icatların neden olduğu ürün yenilikleri, mobil telefonların icadına yol açmıştır (Günay, 2007: 11-12).

\subsubsection{Süreç Yeniliği}

Süreç yeniliği, bir ürünün yapılış veya hizmetin sunuluş yönteminde yapılan değişimler olarak tanımlanmaktadır.Diğer bir değişle süreç yeniliği, ürünün kalite veya maliyetindeki değişimlerde yapılan yeniliklerdir bunlar kullanıcılar tarafından görülemeyebilir.

Süreç yeniliği, mamul ya da hizmetlerin geliştirilmesi, kalite ve güvenirliğin iyileştirilmesi sayesinde müşteriye sunulan değerin artırılmasına katkı sağlar.Ayrıca süreç yeniliği, bir mamul ya da hizmeti üretme veya sunmanın yeni ya da gelişmiş yolunu ifade etmekte ve işletmeye aynı ürünü daha düşük maliyetle üretimi sayesinde daha fazla kar elde etme imkanı vermektedir.Temel olarak işletmenin bir şeyler üretme ve sunma yeteneğinin yenilenmesi ve iyileştirilmesi demek olan süreç yeniliği, pazara daha çok seçeneğin sunulması ya da daha ucuz, daha kaliteli ve daha hızlı olunması gibi birçok şekilde geliştirilebilir (Acaray, 2007: 45-46).

\subsubsection{Organizasyonel Yenilik}

Organizasyonel yenilik; işletmenin işyeri organizasyonundaki veya dış ilişkilerindeki iş pratiklerini yeni bir örgütsel yöntemle yerine getirmesidir. Organizasyonel yenilik yönetimsel maliyetleri veya işlem maliyetlerini düşürerek firmanın performansını arttırmayı, iş tatminini ve böylece emek verimliliğini arttırmayı veya arz etmenin maliyetini düşürmeyi hedeflemektedir. Yeni çalışma ve iş yapış yöntemlerinin geliştirilmesi ya da var olan yöntemlerin firma şartlarına uyarlanarak kullanılmasıdır. İşletmeler sadece ürün ve hizmetlerini geliştirip farklılaştırarak yenilik yapmazlar. Bir işletmenin rekabet avantajı yakalayıp bunu koruyabilmesi için çalışma ve iş yapış yöntemlerini geliştirmesi, farklılaştırması ve yenilemesi gerekir. Bu, geliştirme, farklılaştırma ve yenileme faaliyeti organizasyonel yenilik olarak adlandırılır (Yücel, 2009: 14).

\subsubsection{Pazarlamada Yenilik}

Pazarlama yeniliği, "ürün tasarımı veya ambalajlaması, ürün konumlandırması, ürün tanıtımı (promosyonu) veya fiyatlanlandırmasında önemli değişiklikleri kapsayan yeni bir pazarlama yöntemidir." (OECD, 2006: 53). Pazarlama yeniliği, ürün ya da ambalajda farklı ve yeni tasarımların geliştirilmesi, farklı pazarlama yöntemlerinin gerçekleştirilmesi ve uygulanması veya var olanların iyileştirilerek rekabet avantajının sağlanmasıdır. Bu tanıma ilaveten pazarlama yeniliği teknolojik olmayan yenilik olarak görülmektedir (Elçi, 2007: 12). Inovasyonun avantajlarından biri de pazarlama yeniliğinin marka tanınırlığı ve diğer yandan da ürün farklılığını arttıracağı ileri sürülmektedir (Arslan, 2012: 40-41).

Pazarlama yeniliği, firmanın satışlarını artırmak amacıyla, müşteri ihtiyaçlarına daha başarılı şekilde cevap vermeyi, yeni pazarlar açmayı veya bir firmanın ürününü pazarda yeni bir şekilde konumlandırmayı hedeflemektedir (Güzelsoy,2010: 21). Günümüzde bir çok firmanın internet üzerinde satış yapmasını pazarlama yeniliğine örnek olarak verebiliriz. 


\subsection{Yenilikçi İşletme}

A.B.D.'de Stanford Research Institute tarafından yapılan bir incelemede varlıklarını güçlükle sürdürebilen işletmelere göre, hızlı bir tempoda gelişen işletmelerin yeniliğe ve değişikliğe açık işletmeler olduğu ayrıca daha hızı bir gelişme eğrisine sahip oldukları ve sektörlerinin liderleri oldukları görülmektedir. Bunun yanı sıra yenilikçi işletme, yetkin çalışlara sahip olan ve müşteri bağımlılığını arttıran, müşteri memnuniyeti daha yüksek olan işletmelerdir. İşletmelerin açık bir sistem olması çevreye ve zamana uyum sağlamasını zorunlu kılmaktadır. Yenilik, bu uyumun sağlanmasındaki en etkili unsurdur (Gökçe,2010: 2).

İşletmelerin gösterdikleri yenilikçilik performansı, geniş anlamda bir fikrin ortaya çıkmasından, icat olarak pazarda sunulmasına kadar olan süreci kapsamaktadır. Genel olarak bu süreç, Ar-Ge'den patentleşmeye ve yeni ürün veya hizmetlerin tanıtılmasına kadar kullanılan çalışmaları içermektedir (Yavuz, 2010: 148). Firma yenilikçiliği, işletmeler için önemli bir rekabet avantajı sağlamaktadır.Yenilikçilik işletme için oldukça dinamik bir yetenektir.işsletmeler yenilik çalışmalarıyla, faaliyetlerinin sistematik olarak iyileştirilmesine ve geliştirilmesine katkıda bulunmaktadır (Erdil ve Kitapçı, 2007: 236).Yenilikleri yakından takip eden örgütlerin, rekabetçi üstünlük sağlamanın yanında işletme performanslarını da geliştirdikleri görülmektedir (Karakılıç, 2009: 204).Yenilik ve işletme performansı arasındaki ilişkinin literatürde geniş bir biçimde ve farklı sektörlerde incelendiği görülmektedir. Örneğin, Venkatraman ve Ramanujam (1986) performans ölçümü ile ilgili yaptıkları çalışmada işletme performansının ölçümünde finansal unsurların yanı sıra teknik performans, yenilik performansı gibi finansal olmayan verilere dayanan ölçüm yöntemlerinin de kullanıldığını belirtmiştir. Hurley ve Hult (1998) örgütsel yenilik ile işletmenin pazar yönelimi, örgütsel öğrenme ve performans faktörleri arasındaki pozitif yönlü bir ilişkinin olduğu sonucuna varmışlardır. Hagedoorn ve Cloodt (2003), ileri teknoloji kullanan iş kollarının, yenilik performansı göstergelerini; Ar-Ge girdileri, patent sayıları, patent atıfları ve yeni ürün duyuruları olduğunu ortaya koymuşlardır. Peter F. Drucker' a göre işletmeleri bilgiye dayalı, kapitalist ötesi toplumda şu üç unsuru bünyelerinde bulundurmazlarsa kısa zamanda kendilerini geride kalmış, performans kapasitesinin azalmış ve bunun sonucu olarak da bağımlı bulunduğu o bilgi uzmanlarını kendine çekmek de ve tutmak da dezavantajlı bir durumda olacağı açıktır. Bunlar;

1. Her yaptıkları işte sürekli ve düzenli iyileştirmeler sağlamak (Japonlar- kaizen dedikleri uygulama)

2. Her kuruluş kendi başarılarından bir şeyler öğrenip yeni uygulamalar geliştirmeyi öğrenmelidir.

3. Her kuruluş yenilik geliştirmeyi öğrenmek zorundadır. Ayrıca Drucker’ a göre işletmeler için sistematik yenilikçilik olmazsa olmazıdır ve sistematik yenilikçilik değişimi bir amaca uygun ve düzenli olarak oluşturulan bir süreçtir (Özdaşlı, 2002: 73-74).

Accenture yaptığı araştırmada, yenilikçilik ve rekabetçi avantaj arasında güçlü bir bağ olduğunu keşfetmiştir. Bu araştırmalar, 1990'ların ekonomik resesyonları süresince yeniliklere devam eden Nokia, Samsung, Southwest Airlines, Wal-Mart, Dell ve IKEA gibi şirketlerin, takip eden ekonomik iyileşmeler süresince başarı sağlamak için en iyi konumda 
olduklarını göstermektedir. Joe Tidd ve Ciaran Driver tarafından gerçekleştirilen Bilgi Yönetiminden Stratejik Yeterliliğe: Teknolojik, Piyasa ve Organizasyonel Yeniliğin Ölçülmesi başlıklı bir başka araştırma sonuçları ise, yeniliğin şirketlerin daha fazla ekonomik değer ve hissedar getirisi sağlamalarına yardımcı olduğunu göstermektedir (Tedarik Zincirinde Inovasyon Avantajı, Aralık: 2004).

Genel olarak yeniliğin işletmelere sağladığı faydalar şunlardır:

Tablo 2: Yeniliğin İşletmelere Sağladığı Faydalar

\begin{tabular}{|l|l|}
\hline \multicolumn{2}{|l|}{ Yeniliğin İşletmelere Sağladığı Faydalar } \\
\hline Rekabet üstünlüğü sağlama & Yeni pazarlar oluşturma, \\
\hline Verimlilik artışı & $\begin{array}{l}\text { Ürün hattının ve karmasının } \\
\text { genişletilmesi }\end{array}$ \\
\hline Maliyetlerde düşüş sağlama & $\begin{array}{l}\text { Müşteri tatmininin maksimize } \\
\text { edilmesi }\end{array}$ \\
\hline Pazar payının artması & $\begin{array}{l}\text { Yeni pazarlara girişte kolaylık } \\
\text { sağlama }\end{array}$ \\
\hline Karlılık artışı & $\begin{array}{l}\text { Üretimde, tedarik ve pazarlama } \\
\text { da esneklik sağlama }\end{array}$ \\
\hline $\begin{array}{l}\text { Hammadde kullanımında } \\
\text { etkinliğin sağlanması }\end{array}$ & $\begin{array}{l}\text { Ürün ve hizmetlerin üretim } \\
\text { sürelerinin kısalması ve } \\
\text { firelerin minimizasyonunun } \\
\text { sağlanması }\end{array}$ \\
\hline $\begin{array}{l}\text { Bilginin ekonomik bir değere } \\
\text { dönüşmesi }\end{array}$ & $\begin{array}{l}\text { Çalışma şartlarının iyileştirilmesi } \\
\text { iletişimin tedarikçi ve araçlarla } \\
\text { paylaşımının sağlanması. }\end{array}$ \\
\hline
\end{tabular}

Kaynak: Uzkurt, 2010: 38

İşletmelerin yenilik faaliyetinde bulunmaları sadece o işletme için değil, genel olarak bir ülke ekonomisi için de son derece önemli bir faktördür. Yeniliğin ekonomik büyüme, kalkınma ve rekabet gücü üzerindeki etkileri üzerine odaklandığında, mikro ölçekte yenilik faaliyetlerinin nasıl yapıldığı ve ne gibi etkiler oluşturduğunun anlaşılması açısından etkili olmaktadır (Terzioğlu vd, 2008: 378). 


\subsection{Tüketici Tercihinde Yeniliğin Önemi}

Yenilik, yeni pazarlama bileşenlerinin hedef tüketiciler tarafından yeni olarak algılanması ve kabul edilmesi olarak tanımlanmaktadır. Üretici tarafından yeni olarak sunulan bir pazarlama bileşeninin anlamlı olabilmesi, onun tüketiciler tarafından yeni olarak algılanması ve kabul edilmesine bağlı olmaktadır (İslamoğlu, 2003: 225).

Tüketicilerin pazara yeni çıkan fikirleri, malları ve hizmetleri benimseme eğilimleri; marka sadakati, karar verme, tercih etme ve iletişim teorilerinde önemli bir rol oynayabilir. Eğer tüketicilerin yenilikçilik özelliği olmasaydı, tüketici davranışı pazardaki benzer ürünleri rutin olarak satın alan bir davranışına dönüşürdü. Tüketen bir toplumun doğal bir isteği olan yenilik, pazarın dinamik bir yapı kazanmasına neden olur (Hirschman, 1980: 283).

Drucker (1986); “Bir işin ne olduğuna karar veren müşteridir.Bir mal ya da hizmeti satın almaya istekli olması nedeniyle müşteri, ekonomik kaynakları, anamalı, hammadde ve malzemeleri de kullanılabilir mallar biçimine çevirtir.Bir işletmenin ne üreteceğini düşünmesi, özellikle, işletmenin başarısı ve geleceği yönünden çok önemli değildir. Müşterinin neyi satın alacağı, onun için neyin bir 'değer' taşıdığı konusu en önemli nokta olup, işletmenin çalışma alanının ne olacağı, hangi malları üreteceği ve işletmenin yaşayıp yaşamayacağını belirleyen müşterinin bu konudaki istekleridir" (Kotler, 2000:129). Buradan da anlaşılacağı üzere tüketici piyasadaki yeniliğin farkına varsa bile, ihtiyacını karşılayacağını düşünürse satın alır.Satın aldığı yenilik beklentileriyle uyuşursa benimser.Benimseyen sayısının çoğunluğu ise söz konusu yeniliğin yayılma düzeyini artırır.Yani yeniliğin yayılmasını ve benimsenmesi etkileyen faktörler tüketicinin o yenilikle ilgili memnuniyeti ile doğru orantılıdır.Tabi tüketicinin, yeniliğin farkına varmasını ve satın almasını sağlamak işletmenin yeniliği pazarlayabilme gücüyle de yakından ilgilidir. Bazen bazı yenilikler ihtiyaç gibi görünmese de söz konusu yeniliği icat eden işletme etkili iletişim yöntemleri ve diğer yöntemlerle, tüketiciye o yeniliği ihtiyaçmış gibi düşündürüp satın alınması sağlanmaktadır.

Tüketici yenilikçiliğini, Steenkamp, Hofstede ve Wedel (1999: 56), bireylerin daha önceki ürün seçme ve tüketim alışkanlıkları yerine, yeni olan ürün ve markaları satın alma eğilimleri olarak tanımlamaktadırlar. Tüketicilerin yenilikçilik düzeyinin ölçülmesinin önemini Telis, Yin ve Bell (2009:1) birkaç nedene bağlamaktadırlar.Bu nedenler; pazarların giderek globalleşmesi sonucunda firmaların pazarlar arasındaki tüketicilerin farklılıklarını ve benzerliklerini daha iyi anlamaya ihtiyaç duyması, firmaların giderek daha fazla sıklıkta yeni ürünü pazara sürerken farklı pazarlardaki tüketicilerin yeni ürünlere karşı eğilimlerini öğrenmeye daha fazla ihtiyaç duymasıdır.

Bülbül ve Özoğlu (2014:46) tüketicilerin yeni ürün satın alımlarında algılanan riskin satın almadan kaçınmaya neden olduğu ilgi alanına özgü tüketici yenilikçiliğinin, kendiyle uyumun ve tatmininin ise satın almayı teşvik edici olduğunu belirtmiştir.

Tüketicilerin her ürün ya da hizmete karşı gösterdikleri yenilikçi davranış tepkisi aynı değildir.Bazıları modaya eğimli, bazıları şarap tutkunu bazıları ise film meraklısı olabilmektedirler.Yüksek yenilikçiliğe sahip tüketiciler dahi her yeniliğe her zaman aynı tutumu göstermeyebilirler.Ancak ürün kategorileri benzer özellikler gösteriyorsa tüketicilerin yenilikçi davranışları da benzerlik gösterebilmektedir (Goldsmith ve Foxall, 2003: 323; Nasution ve Garnida, 2010: 2). 


\section{ARAŞTIRMA VE YÖNTEM}

\subsection{Araştırmanın Amacı Ve Önemi}

Günümüz rekabet ortamının en önemli kavramlarından biri yeniliktir.İşletmeler büyük bir yarış halinde kendi ürünlerini tüketicilere beğendirme çabasına girmişlerdir.Bu ortamda bilgi teknolojisini yakalayamamış, yenilik yapamayan işletmelerin ayakta kalması zor gözükmektedir.

Yenilik artık yalnızca Ar-Ge departmanının sorumluluğunda olmayıp işletmeyi çevreleyen tüm faktörlerin ortak katılımıyla gerçekleştirilebilecek bir boyut kazanmıştır.Yeni ürünler firmalar tarafından büyük bir tanıtım kampanyasıyla birlikte tüketicilerin kullanımına sunulmaktadır.Iş̧letmelerin yaptıkları yenilik yatırımları her geçen gün büyümektedir. Bu ortamda tüketicilerin yeniliğe bakış açıları önem kazanmaktadır. İşletmelerin yeniliğe verdikleri bu önem tüketiciler nezlinde ne kadar önemsenmektedir? İnsanlar herhangi bir ürün satın alırken yeniliğe ne kadar dikkat etmektedirler? gibi sorular işletmelere farklı bir bakış açısı getirecek, yeniliğin toplum içerisindeki önemini göstermiş olacaktır.

Bu çalışma tüketicilerin yeniliğe bakış açılarını göstermekte ve ürün tercihlerinde yeniliğin önemini ortaya koymaktadır.Bu amaç doğrultusunda ilk olarak yenilik, yenilikçi işletme ve tüketici tercihlerinde yeniliğin önemi konuları işlenmiştir. Çalışmanın takip eden bölümünde tüketicilerin yeniliğe bakış açıları ve ürün tercihlerinde yeniliğin önemini anlatan bir araştırmaya yer verilmiş, elde edilen bulgular yorumlanarak sonuçlar ortaya konmuştur.

\subsection{Araştırmanın Yöntemi}

Tüketici tercihlerinde yeniliğin önemini açıklayan bu araştırma benimsenen yöntem açısından; tümden gelim yönteminin uygulanması, nicel verilerin kullanılması, objektif değerlendirmelerde bulunulması gibi nedenlerle pozitivist bir araştırmadır. Bununla birlikte; araştırma konusu, yenilik ile tüketici algıları arasındaki ilişkilerin incelenmesiyle açıklandığı için açıklayıcı bir araştırmadır. Araştırma konusu veri edinme yöntemine göre ise anket yöntemi kullanıldığı için anket araştırmasıdır.

\subsection{Veri Toplama Yöntemi}

Çalışmada veri toplama aracı olarak niceliksel bir yöntem olan anket yönteminden yararlanılmış, 5'li Likert ölçeği kullanılmıştır. Anket formu literatür taramasının ardından oluşturulmuş ve alanında uzman akademisyenlerin görüşleri doğrultusunda yeniden gözden geçirilerek pilot uygulamaya tabi tutulmuştur. Pilot uygulama ile 40 kişiden elde edilen veriler doğrultusunda, anket formunun güvenilirliği ve geçerliliği test edilerek anket formuna nihai hali kazandırılmıştır.

Anket formu üç bölümden oluşmaktadır.ilk bölümde tüketicilerin genel olarak yeniliğe ve yenilikçi işletmelere bakış açılarını değerlendiren ifadeler yer almaktadır. Anket formunda yer alan maddeler Uzkurt, (2008, s.269-270)'un yeniliğin işletmelere getirdiği faydaları gösteren ifadelerinden yararlanılarak hazırlanmıştır. 
Anket formunun ikinci bölümünde tüketicilerin dizüstü bilgisayar alırken ürünün yenilikçi özelliklerine ne kadar dikkat ettiklerini gösteren ifadeler yer almaktadır. Anketi dolduran tüketiciler teknolojik bir ürün olan diz üstü bilgisayarı satın alırken ürünün yenilikçi özelliklerine dikkat etmişler midir?sorusuna yanıt aranmaktadır.

Anket formunun son bölümünde, katılımcıların kişisel bilgilerinin yer aldığı ve sekiz ifadeden oluşan "Kişisel Bilgiler" formuna yer verilmiştir.

\subsection{Evren ve Örneklem}

Araştırmanın ana kütlesini Afyonkarahisar ilinde yaşayan dizüstü bilgisayar kullanıcıları oluşturmaktadır. Ana kütlenin tamamına ulaşmak mümkün olmadığından örneklem alma yoluna gidilmiştir. Araştırmada örnekleme yöntemi olarak "Kolayda Örnekleme Yöntemi" uygulanmıştır. 40 adet anket formu eksik ya da yanlış kodlama nedeniyle analiz dışı tutularak toplamda 310 anket formu analize dâhil edilmiştir.

Hazırlanan anket formu 11 Ocak- 27 Ocak 2015 tarihleri arasında Afyonkarahisar ilindeki bazı teknoloji mağazalarında, üniversitede ve genel olarak il merkezinde doldurulmuştur. Teknoloji mağazalarının seçilmesindeki amaç ürünler hakkında daha fazla bilgiye sahip olan bir örnek kitlenin oluşturulması içindir.Bunun yanında yenilikleri daha çok takip ettiği düşünülen üniversite öğrencileri de ankete dahil edilmiştir.

\section{ANALIZ VE BULGULAR}

\subsection{Verilerin Analizi}

Araştırmada anket yöntemiyle toplanan veriler SPSS 20.0 (StatisticalPackage for the Social Sciences) programından faydalanılarak analiz edilmiş, frekans-yüzde dağılımları, aritmetik ortalama ve standart sapma değerleri hesaplanarak betimlenmiştir.Katılımcıların konuya ilişkin görüşleri ile demografik özelliklerinin karşılaştırılmasında ilişkisiz ölçümler için " $\mathrm{t}$ testi" ve "Varyans (ANOVA) Analizi"nden yararlanılmıştır.

\subsection{Geçerlilik ve Güvenilirlik Analizi}

Güvenilirlik analizinde iç tutarlılık yöntemiyle hesaplanan Alfa Modeli (Cronbach Alpha Coefficient) dikkate alınmıştır. Alfa katsayısı, ölçekte yer alan k ifadenin varyansları toplamının genel varyansa oranlanması ile elde edilen ağırlıklı standart değişim ortalaması olarak ifade edilmektedir. Alfa katsayısı, ölçeğin güvenilirliği hesaplanırken aşağıdaki derecelendirmeye göre değerlendirilir (Özdamar, 1999: 513-522).

$0.00 \leq \alpha<0.40$ Ölçek güvenilir değil,

$0.40 \leq \alpha<0.60$ Düşük güvenirlik,

$0.60 \leq \alpha<0.80$ Ölçek güvenilir,

$0.80 \leq \alpha<1.00$ Ölçeğin güvenirliği yüksek. 


\section{Tablo 3:Cronbach's Alpha Analizi}

ReliabilityStatistics

\begin{tabular}{|l|l|}
\hline Cronbach's Alpha & N of Items \\
\hline 817 & 16 \\
\hline
\end{tabular}

Güvenilirlik analizi sonuçlarına göre anket 0.817 katsayı ile güvenilir bir anket kategorisini girmektedir.

\subsection{Katılımcıların Demografik Özelliklerine Illişkin Tanımlayıcı Bilgiler}

Çalışmada katılımcıların demografik özelliklerine ilişkin tanımlayıcı istatistikler frekans ve yüzde dağılımlarına göre değerlendirilmiştir. Tablo 4, katılımcıların demografik özelliklerine ilişkin istatistikî verileri içermektedir.

Katılımcılar yaş, cinsiyet, medeni durum, öğrenim durumu, meslek, gelir gibi değişkenlere göre sınıflandırılmıştır. Bunun yanında katılımcıların laptoba ödedikleri fiyatta değişkenlere dahil edilmiştir. Böylece yenilikçi firmalara tüketicilerin verdikleri önemi demografik faktörlerla karşılaştıma yaparak analiz etme imkanı doğmuştur.

Laptoba ödenen fiyat ise maliyet faktörü ile yenilikçi ürün tercihi arasındaki ilişkiyi araştırmaya imkan tanımaktadır. 
Tablo 4: Katılımcıların Demografik Özellikleri

\begin{tabular}{|c|c|c|c|c|c|}
\hline DEĞiŞKENLER & $\mathrm{N}$ & Yüzde & DEĞiŞKENLER & & Yüzde \\
\hline Cinsiyet & & & Medeni Durum & & \\
\hline Erkek & 198 & 63,9 & Evli & 147 & 47,4 \\
\hline Kadın & 112 & 36,1 & Bekar & 163 & 52,6 \\
\hline Toplam & 310 & 100,0 & Toplam & 310 & 100,0 \\
\hline Yaş Grupları & & & Öğrenim & & \\
\hline $0-20$ & 54 & 17,4 & İlköğretim & 38 & 12,3 \\
\hline $20-30$ & 118 & 38,1 & Lise & 118 & 38,1 \\
\hline $30-40$ & 80 & 25,8 & Önlisans & 100 & 32,3 \\
\hline $40-50$ & 40 & 12,9 & Lisans & 45 & 14,5 \\
\hline 50 ve üzeri & 18 & 5,5 & Lisans üstü & 9 & 2,9 \\
\hline Toplam & 310 & 100,0 & Toplam & 310 & 100,0 \\
\hline Meslek & & & Gelir & & \\
\hline Memur & 21 & 6,8 & $0-1000$ & 135 & 43,5 \\
\hline İşçi & 25 & 8,1 & $1000-2000$ & 71 & 22,9 \\
\hline Ev hanımı & 12 & 3,9 & $2000-3000$ & 62 & 20,0 \\
\hline Öğrenci & 86 & 27,7 & $3000-4000$ & 24 & 7,7 \\
\hline Öğretmen & 19 & 6,1 & 4000 ve üzeri & 18 & 5,8 \\
\hline Emekli & 5 & 1,6 & Toplam & 310 & 100,0 \\
\hline Serbest meslek & 98 & 31,6 & Laptop Fiyatı & & \\
\hline İşsiz & 5 & 1,6 & $0-1000$ & 40 & 12,9 \\
\hline Çiftçi & 5 & 1,6 & $1000-1500$ & 108 & 34,8 \\
\hline Diğer & 34 & 11,0 & $1500-2000$ & 103 & 33,2 \\
\hline \multirow[t]{3}{*}{ Toplam } & 310 & 100,0 & $2000-2500$ & 33 & 10,6 \\
\hline & & & 2500 ve üzeri & 26 & 8,4 \\
\hline & & & Toplam & 310 & 100,0 \\
\hline
\end{tabular}

Tablo 4'e göre katılımcıların \%63.9'u erkek, \%36.1'i kadın olup büyük bir çoğunluğu (\%64) 20-40 yaş aralığındadır.Katılımcıların yaklaşık \% 50'si üniversite mezunudur. Ankete katılan kişilerin gelir durumu \% 43 ile 0-1000 TL arasında, \%22.9 ile 1000-2000 TL arasında ve \%20 ile 2000-3000 TL arasında değişmektedir. Katılımcıların büyük bir çoğunluğu satın aldıkları diz üstü bilgisayara 1000-3000 TL arasında bir fiyat ödemiştir. 


\subsection{Katılımcıların Yenilik Ve Yenilikçi İşletmelerle İlgili Algıları}

Tablo 5'de tüketicilerin yenilikçi işletmelere ve onların ürünlerine bakış açıları incelenmiştir.

Tablo 5: Tüketicilerin Yeniliğe illişkin İnançları

\begin{tabular}{|l|l|l|l|}
\hline Yenilik Algısıyla ilgili i̇fadeler & $\mathrm{N}$ & Ortalama & $\begin{array}{l}\text { Standart } \\
\text { Sapma } \\
\text { ss }\end{array}$ \\
\hline İşletmeler yenilik yaparak büyüyebilirler & 310 & 4,1677 &, 87998 \\
\hline Yenilik işletmeye rekabetçi bir avantaj sağlar & 310 & 3,9677 & 1,04227 \\
\hline $\begin{array}{l}\text { İşletmelerin yenilikler } \\
\text { reklamlardan daha etkilidir }\end{array}$ & 310 & 3,7129 & 1,03256 \\
\hline $\begin{array}{l}\text { İşletme imajını yükselten en önemli faktör } \\
\text { yeniliktir }\end{array}$ & 310 & 4,0097 & 1,00641 \\
\hline $\begin{array}{l}\text { İşletmeler bütçelerinin önemli bir kısmını } \\
\text { yeniliğe ayırmalıdır }\end{array}$ & 310 & 3,7161 & 1,01608 \\
\hline $\begin{array}{l}\text { Yenilik işletmeyi rakiplerinden ayıran en } \\
\text { önemli faktördür }\end{array}$ & 310 & 3,9484 & 1,01314 \\
\hline $\begin{array}{l}\text { Yenilikçi bir işletme tüketici gözünden en } \\
\text { değerli marka konumundadır }\end{array}$ & 310 & 3,6806 & 1,06334 \\
\hline $\begin{array}{l}\text { Yenilikçi bir işletmeye karşı marka sadakati } \\
\text { daha fazladır }\end{array}$ & 310 & 3,7516 & 1,05185 \\
\hline $\begin{array}{l}\text { İşletmeler yeni fikirler konusunda } \\
\text { tüketicilerin görüşlerini almalıdır }\end{array}$ & 310 & 4,0968 & 1,01939 \\
\hline \begin{tabular}{l} 
Yeni ürünler her zaman daha kalitelidir. \\
\hline $\begin{array}{l}\text { Yeni ürünler meydana getiren bir işletmenin } \\
\text { pazar payı büyür }\end{array}$
\end{tabular} & 310 & 3,0065 & 1,38413 \\
\hline $\begin{array}{l}\text { Yenilik yalnızca ürün satışında değil satıştan } \\
\text { sonraki süreçleride kapsamalıdır }\end{array}$ & 310 & 3,9419 & 1,07528 \\
\hline $\begin{array}{l}\text { Yeni ürünü satın alan tüketicilerin } \\
\text { memnuniyet düzeyleri daha yüksek olur }\end{array}$ & 310 & 3,6839 & 1,11915 \\
\hline $\begin{array}{l}\text { Yenilik tüketicinin satın alma kararını } \\
\text { etkileyen en önemli faktördür }\end{array}$ & 310 & 3,9484 & 1,01314 \\
\hline
\end{tabular}

Tablo 5'e bakıldığında tüketicilerin yeniliğe karşı çok olumlu bir bakış açısına sahip oldukları görülmektedir. Ankete katılanlar en çok "işletmeler yenilik yaparak büyüyebilirler", "işletme imajını yükselten en önemli faktör yeniliktir", "İ̧̧letmeler yeni fikirler konusunda tüketicilerin görüşlerini almalıdır" ifadelerine katılmaktadır. Ortalaması yüksek olmasına karşın en az katıldıkları görüş ise "yeni ürünler her zaman daha kalitelidir" ifadesidir. Diğer tüm görüşlerin ortalaması da 3.0'dan daha yüksektir. 
Tablo 5 genel olarak incelendiğinde yeniliğin tüketiciler açsından çok önemli ve etkili bir faktör olduğu, işletmelerin performansı açısından yeniliğin oldukça önemsendiği görülmektedir.iş̧letmeler yenilik yaparken tüketicilerinde düşüncesini almalı ve açık inovasyona önem vermelidirler.Bunun yanında yenilikçi bir işletmenin imajı yüksek görülmekte, marka değeri artmaktadır.Yenilikçi firmaların ürünleri tüketicileri daha çok tatmin etmekte ve marka sadakati açısından işletmelere avantaj sağlamaktadır.Yenilik yalnızca üründe meydana gelen değişiklikler olarak algılanmamalı bir süreç içerisinde ele alınmalıdır. Katılımcıların büyük bir çoğunluğu yeniliğin tüketicilerin satın alma kararını etkileyen en önemli faktör olduğunu düşünmektedir. Buradan da anlaşılacağı gibi yenilik satın alma kararı üzerine doğrudan bir etkiye sahip olmakta, bazen en önemli faktör olarak görülmektedir. Tüm bu veriler birlikte değerlendirildiğinde yeniliğin büyük bir rekabet avantajı yaratacağı ve firmanın pazar payını arttıracağı çok açık bir biçimde görülmektedir.

\section{5. Ürün Tercihinde Yeniliğin Önemi}

Tablo 6'da tüketicilerin dizüstü bilgisayar alırken yeniliğe verdikleri önem gösterilmektedir.Tüketiciler teknolojik bir ürün olan dizüstü bilgisayarı satın alırlarken ürünün yeni ve güncel olmasına dikkat etmişlerdir.

Tablo 6: Ürün Tercihinde Yeniliğin Önemi

\begin{tabular}{|l|l|l|l|}
\hline Ürün Tercihinde Yeniliğin Önemi & $N$ & Ortalama & $\begin{array}{l}\text { Standart } \\
\text { Sapma } \\
\text { ss }\end{array}$ \\
\hline $\begin{array}{l}\text { Satın aldığım dizüstü bilgisayar markasının } \\
\text { yenilikçi olmasına dikkat ettim. }\end{array}$ & 310 & 3,6806 & 1,20326 \\
\hline $\begin{array}{l}\text { Satın aldığım dizüstü bilgisayarı tercih etme sebebim } \\
\text { başka hiç bir markada bulunmayan yenilikçi } \\
\text { özelliklerinin olmasıydı. }\end{array}$ & 310 & 3,5935 & 1,08653 \\
\hline $\begin{array}{l}\text { Satın aldığım dizüstü bilgisayarın fiyatından çok yenilikçi } \\
\text { özelliklerine dikkat ettim. }\end{array}$ & 310 & 3,6258 & 1,14144 \\
\hline $\begin{array}{l}\text { Satın aldığım dizüstü bilgisayarın reklamından çok } \\
\text { yenilikçi özelliklerine dikkat ettim }\end{array}$ & 310 & 3,6710 & 1,16369 \\
\hline $\begin{array}{l}\text { Satın aldığım dizüstü bilgisayarın kolay bulunmasından } \\
\text { çok yenilikçi özelliklerine dikkat ettim. }\end{array}$ & 310 & 3,5581 & 1,17478 \\
\hline $\begin{array}{l}\text { Satın aldığım dizüstü bilgisayarı arkadaşlarımın } \\
\text { tavsiyeleriyle değil yenilikçi özelliklerinden dolayı satın } \\
\text { aldım. }\end{array}$ & 310 & 3,7000 & 1,19749 \\
\hline
\end{tabular}

Tablo 6'ya bakıldığında tüketicilerin dizüstü bilgisayar satın alırken yenilikçi işletmeleri tercih ettikleri ve yeni özelliklerinden dolayı sahip oldukları bilgisayarları satın aldıkları görülmektedir.Bunun yanında reklam, dağıtım ve fiyat gibi pazarlama stratejilerinden çok yenilikçi özelliklerin daha önemli görüldüğü anlaşılmaktadır. 
Ağızdan ağıza pazarlamayı gösteren "dizüstü bilgisayarı arkadaşlarımın tavsiyeleriyle değil yenilikçi özelliklerinden dolayı satın aldım" ifadesi ise yeniliğin arkadaş tavsiyesinden daha önemli olduğunu göstermektedir. Tablo 6 'da ki değerlerin tamamının yüksek olmasından dolayı ankete katılan kişilerin tüm bu ifadeleri doğru olarak kabul ettikleri söylenebilir. Katılımcılar fiyat ve yenilik ikilemi arasında kaldıklarında yeniliği tercih etmişlerdir.Fiyatın yüksek olmasından ziyade yeni bir ürün olması tüketicileri daha fazla etkilemektedir.

Tablo 6 genel olarak incelendiğinde pazarlama çabalarının dizüstü bilgisayar kullanıcıları tarafından yenilik kadar fazla önemsenmediği, ürün tercihinde yeniliğin daha belirleyici olduğu görülmektedir. Günümüz tüketicileri her zaman yeni ve güncel ürünleri tercih etmektedir.Bu düşüncenin psikolojik, toplumsal ve ekonomik gerekçeleri olabilir.Insanlar diğer tüketiciler karşısında geri kalmamak, imaj oluşturmak, teknolojiyi yakalamak ve ekonomik açıdan doğru karar verebilmek için yeni ürünlere yönelmektedir.

Günümüzde mesaj bombardımanına tutulmuş olan tüketiciler diğer ürünlerden farklı, yenilikçi çözümlere daha fazla itibar etmektedir.Bu durum kuşkusuz tutundurma faaliyetlerinin gereksiz olduğunu göstermemektedir ancak yenilik işletme açısından daha etkili bir tanıtım faaliyeti olmaktadır.Reklamların çoğu ücretli bir biçimde yapılmakta ve direk olarak tüketiciyi etkilememektedir.Yenilik ise tüketicileri daha doğrudan ilgilendirmekte ve onların yararına olmaktadır.

\subsection{Katılımcıların Yeniliğe iliş̧kin Görüşlerinin Karşılaştırılması}

Tablo 7, katılımcıların yaşı ile yeniliğe karşı tutumlarının karşılaştıııldığı varyans analizi sonuçlarını içermektedir. Tüketicilerin yaşları ile yeniliğe bakış açıları arasında anlamlı bir ilişkinin olup olmadığı analiz edilmiştir.

Tablo 7: Yenilikle İlgili Görüşleri Katılımcıların Yaşıyla Karşılaştıran Varyans Analizi Sonuçları

\begin{tabular}{|c|c|c|c|c|c|c|c|c|}
\hline & \multirow[t]{2}{*}{$\mathrm{N}$} & \multirow[t]{2}{*}{ Mean } & \multirow[t]{2}{*}{$\begin{array}{c}\text { Std. } \\
\text { Deviation }\end{array}$} & \multirow[t]{2}{*}{$\begin{array}{l}\text { Std. } \\
\text { Error }\end{array}$} & \multicolumn{2}{|c|}{$\begin{array}{l}\text { 95\% Confidence Interval } \\
\text { for Mean }\end{array}$} & \multirow[t]{2}{*}{$\mathrm{F}$} & \multirow{2}{*}{$\begin{array}{l}\text { Sig. } \\
\text { (p) }\end{array}$} \\
\hline & & & & & LowerBound & UpperBound & & \\
\hline $0-20$ & 54 & 3,5880 & ,47358 & ,06445 & 3,4587 & 3,7172 & 3,424 & , 005 \\
\hline $20-30$ & 118 & 3,7569 & ,52798 & ,04860 & 3,6606 & 3,8531 & & \\
\hline $30-40$ & 80 & 3,8406 & ,59292 & ,06629 & 3,7087 & 3,9726 & & \\
\hline $40-50$ & 40 & 3,9000 & ,61836 & 09777, & 3,7022 & 4,0978 & & \\
\hline $\mid \begin{array}{ll}50 & \text { ve } \\
\text { üzeri } & \end{array}$ & 18 & 3,7904 & ,55986 & 13579, & 3,5026 & 4,0783 & & \\
\hline Total & 310 & 3,7645 & 56142 & ,03189 & 3,7018 & 3,8273 & & \\
\hline
\end{tabular}

Tablo 7 incelendiğinde yaş farkı ile yenilik algısı arasında anlamlı bir ilişki olduğu görülmektedir $(p=.005<p=.05)$. Buna göre özellikle yaş ilerledikçe yeniliğe verilen önem artmaktadır.Tüm yaş aralıklarında yenilik önemli olarak algılanmakta iken özellikle 30 ve 50 
yaş aralığındaki kişilerin yeniliği daha fazla önemsedikleri görülmektedir.0-20 yaş aralığındaki tüketicilerin zaten sürekli bir değişim ve dönüşüm çağında dünyaya gelmiş olmaları, orta yaşlardaki kişilerin onlardan yenilikler karşısında daha fazla etkilenmelerine yol açmış olabilir.Orta ve ilerlemiş yaşlardaki tüketiciler günümüzde yeniliğin değerini eski dönemle karşılaştırarak daha fazla anlamaktadırlar.Z kuşağı olarak adlandırılan 2000 ve daha sonra doğanlar için yenilik hayatın bir parçası ve olağan bir durum olarak algılanmaktadır.Bu sonuç yenilik her zaman genç yaşlardaki kişiler tarafından önemsenir düşüncesinden farklıdır. Yenilik algısı toplumun tüm kesimleri tarafından değerli kabul edilmektedir. Orta yaştaki insanlarda yeniliği önemsemekte ve tercihlerini yeni ürünlerden yana kullanmaktadırlar.

Tablo 8:Yenilikle İIgili Görüşleri Katılımcıların Gelir Durumuna Göre Karşılaştıran Varyans Analizi Sonuçları

\begin{tabular}{|c|c|c|c|c|c|c|c|c|}
\hline & \multirow[t]{2}{*}{$\mathrm{N}$} & \multirow[t]{2}{*}{ Mean } & \multirow[t]{2}{*}{$\begin{array}{c}\text { Std. } \\
\text { Deviation }\end{array}$} & \multirow[t]{2}{*}{$\begin{array}{l}\text { Std. } \\
\text { Error }\end{array}$} & \multicolumn{2}{|c|}{$\begin{array}{l}\text { 95\% Confidence } \\
\text { Interval for Mean }\end{array}$} & \multirow[t]{2}{*}{$F$} & \multirow[t]{2}{*}{ Sig. } \\
\hline & & & & & $\begin{array}{l}\text { Lower } \\
\text { Bound }\end{array}$ & $\begin{array}{l}\text { Upper } \\
\text { Bound }\end{array}$ & & \\
\hline $0-1000$ & 135 & 3,4481 & 81280 & ,06995 & 3,3098 & 3,5865 & 3,792 & ,005 \\
\hline $1000-2000$ & 71 & 3,6925 & 89649, & 10639, & 3,4803 & 3,9047 & & \\
\hline $2000-3000$ & 62 & 3,8575 & 68009, & 08637, & 3,6848 & 4,0302 & & \\
\hline $3000-4000$ & 24 & 3,8264 & 67652 & 13809, & 3,5407 & 4,1121 & & \\
\hline $4000+$ & 18 & 3,8426 & 80129, & 18887, & 3,4441 & 4,2411 & & \\
\hline Total & 310 & 3,6382 & 81274 & ,04616 & 3,5473 & 3,7290 & & \\
\hline
\end{tabular}

Tablo 8'ebakıldığında gelir durumu ile ürün tercihinde yeniliğin önemi konusunda anlamlı bir ilişki ortaya çıkmaktadır ( $p=.005<p=.05)$. Buna göre tüketicilerin gelir durumu arttıkça üründen bekledikleri yenilik düzeyleri de artmaktadır. Daha yüksek gelire sahip olan kişiler daha yenilikçi ürünleri tercih etmektedirler. Bu kişiler pazarlama çabalarından çok yeniliklere dikkat etmektedirler.

Yeni ürünlere ulaşmak ile gelir düzeyinin hiç kuşkusuz önemli bir ilişkisi vardır. Maddi olanakları yüksek olan tüketiciler satın alma güçlerinin fazla olmasından dolayı pazardaki yenilikleri daha çok takip etmekte, farklı ve yenilikçi markalara yönelmektedir. Tablo 8'e göre özellikle 2000 TL'den daha fazla gelire sahip olan kişiler dizüstü bilgisayar tercihlerini daha çok farklılaşmış ürünlerden yana kullanmaktadır. 
Tablo 9:Yenilikle İlgili Görüşleri Katılımcıların Dizüstü Bilgisayara Ödedikleri Ücretle Karşılaştıran Varyans Analizi Sonuçları

\begin{tabular}{|c|c|c|c|c|c|c|c|c|}
\hline & \multirow[t]{2}{*}{$\mathrm{N}$} & \multirow[t]{2}{*}{ Mean } & \multirow[t]{2}{*}{$\begin{array}{c}\text { Std. } \\
\text { Deviation }\end{array}$} & \multirow[t]{2}{*}{$\begin{array}{l}\text { Std. } \\
\text { Error }\end{array}$} & \multicolumn{2}{|c|}{$\begin{array}{c}95 \% \text { Confidence Interval } \\
\text { for Mean }\end{array}$} & \multirow[t]{2}{*}{$\mathrm{F}$} & \multirow[t]{2}{*}{ Sig. } \\
\hline & & & & & $\begin{array}{l}\text { Lower } \\
\text { Bound }\end{array}$ & $\begin{array}{l}\text { Upper } \\
\text { Bound }\end{array}$ & & \\
\hline $0-1000$ & 40 & 3,5125 & 54121 & ,08557 & 3,3394 & 3,6856 & & \\
\hline $1000-1500$ & 108 & 3,8223 & 56306 & 05418 & 3,7149 & 3,9297 & 3,615 & ,007 \\
\hline $1500-2000$ & 103 & 3,8477 & ,57414 & ,05657 & 3,7355 & 3,9599 & & \\
\hline $200-2500$ & 33 & 3,6098 & ,50583 & 08805 & 3,4305 & 3,7892 & & \\
\hline $2500+$ & 26 & 3,7788 & ,48290 & 09471 & 3,5838 & 3,9739 & & \\
\hline Total & 310 & 3,7645 & ,56142 & ,03189 & 3,7018 & 3,8273 & & \\
\hline
\end{tabular}

Tablo 9'a göre dizüstü bilgisayara daha fazla ücret ödeyenlerin yeniliğe bakış açılarının daha olumlu olduğu sonucu çıkmaktadır. Dizüstü bilgisayar satın alırken daha fazla ücret ödemiş olan kişiler genel olarak yeniliğe daha fazla önem vermekte, yenilikçi işletmeleri daha değerli olarak algılamaktadırlar. Bu kişiler için yenilik firmanın imajına olumlu bir etki yapmakta, işletmelerini büyütmekte, pazar paylarını arttırarak tüketicileri daha fazla memnun etmektedir. Bu nedenle yeni ürünlere daha fazla ücret ödemeyi kabul etmektedirler.

Tablo 10: Satın Almada Yenilikle İlgili Görüşleri Katılımcıların Dizüstü Bilgisayara Ödedikleri Ücretle Karşılaştıran Varyans Analizi Sonuçları

\begin{tabular}{|c|c|c|c|c|c|c|c|c|}
\hline & \multirow[t]{2}{*}{$\mathrm{N}$} & \multirow[t]{2}{*}{ Mean } & \multirow[t]{2}{*}{$\begin{array}{l}\text { Std. } \\
\text { Deviation }\end{array}$} & \multirow[t]{2}{*}{$\begin{array}{l}\text { Std. } \\
\text { Error }\end{array}$} & \multicolumn{2}{|c|}{$\begin{array}{c}95 \% \text { Confidence Interval } \\
\text { for Mean }\end{array}$} & \multirow[t]{2}{*}{$F$} & \multirow[t]{2}{*}{ Sig. } \\
\hline & & & & & $\begin{array}{l}\text { Lower } \\
\text { Bound }\end{array}$ & $\begin{array}{l}\text { Upper } \\
\text { Bound }\end{array}$ & & \\
\hline $0-1000$ & 40 & 3,1917 & 76938 & 12165, & 2,9456 & 3,4377 & 6,071 & ,000 \\
\hline $1000-1500$ & 108 & 3,6080 & 83639, & 08048 & 3,4485 & 3,7676 & & \\
\hline $1500-2000$ & 103 & 3,8544 & 75972 & 07486, & 3,7059 & 4,0028 & & \\
\hline $200-2500$ & 33 & 3,4495 & ,86149 & 14997 & 3,1440 & 3,7550 & & \\
\hline $2500+$ & 26 & 3,8333 & ,58310 & 11435 & 3,5978 & 4,0689 & & \\
\hline Total & 310 & 3,6382 & 81274 & 04616 & 3,5473 & 3,7290 & & \\
\hline
\end{tabular}

Tablo 10'a göredizüstü bilgisayara daha fazla ücret ödeyen tüketiciler, ürünün yenilikçi olmasına dikkat etmişlerdir. Buradan çıkarılabilecek sonuç tüketicilerin yeni ürünlere daha fazla para ödemeye istekli olduklarıdır. İşletmeler yeni bir ürün ürettiklerinde bunu daha yüksek bir ücrete satabilmekte ve daha fazla bir katma değer elde etmektedirler. Tüketiciler ise hem yeni ürüne daha fazla ücret ödemekte hem de satın aldıkları üründen daha fazla memnun olmaktadırlar. 
Çıkan sonuçlara göre dizüstü bilgisayara ödenen ücret ile yenilikçi ürünlere gösterilen önem arasında anlamlı bir ilişki vardır $(p=.000<p=.05)$.

\section{SONUÇ}

Yenilik günümüzün en önemli kavramlarından bir tanesidir.Ülkeler açısından, işletmeler açısından gelişimin ve kalkınmanın anahtarıdır.Son yıllarda yaşanan büyük değişimler teknoloji ve bilişim alanında yeniliklere yol açmaktadır.iletişimin gelişmesi, küresel pazar yapıları, rekabetin artması yeniliğin kaynakları olarak ortaya çıkmıştır.Ürün ve hizmetlerdeki köklü değişim tüketicilerin yararına olmaktadır.Günümüz tüketicileri yeniliğe alışmıştır. Artık sürekli yenilikler yapmadan müşterileri tatmin etmek imkansız bir hale gelmiştir. Bir anlamda yenilik sıradanlaşmış, organizasyonların zorunlu bir parçası haline gelmiştir.Mevcut durumda Ar-Ge departmanı olmayan ve yenilikle ilgili çalışmalar yapmayan uluslararası bir şirket bulmak oldukça güçleşmiştir.

İşletmelerde yenilik yalnızca üründe köklü bir değişim anlamına gelmemektedir.Bazen tutundurmada bazen dağıtımda bazen de satış tekniklerinde ve fiyatlandırmada yenilikler yapılabilmektedir.Yenilikçi işletmeler yeniliği Ar-Ge departmanıyla sınırlı, kapalı bir sistem gibi ele almamaktadır.Müşterilerin, çalışanların, paydaşların her birinin katılımlarıyla yenilikler gerçekleştirilmektedir. Tüketiciler tarafından beğenilmeyen bir yenilik ne kadar radikal ve köklü olursa olsun günümüz işletme literatüründe yenilik olarak görülmemektedir. Dolayısıyla müşteri odaklı pazarlama anlayışı özellikle yenilikler konusunda gündeme gelmektedir.Bir yeniliğin farklılık derecesinden çok müşteriyi memnun etme oranı işletmeler açısından daha önemlidir.

Tüketiciler açısından yenilik kullandıkları ürün ve hizmetlerin değişmesi ve sürekli bir iyileşme halinde olmasını ifade etmektedir.Bir kaç sene önce alınan teknolojik bir ürün eskimektedir.Yeni ürün pahalı ve maliyetlide olsa tüketiciler tarafından tercih edilmektedir.Bu durum yeni ürünün toplum içerisinde ve global ölçekte hızlı bir şekilde yayılmasına yol açmaktadır.Yeniliklerin dünya ölçeğine yayılması da küresel ticareti canlı tutan en önemli faktör olmaktadır.

Bu çalışmada tüketicilerin yenilikçi işletmelere bakış açıları ve ürün alırken yeniliğe ne kadar dikkat ettikleri araştırılmaktadır. Çalışmadan elde edilen sonuçlara göre; yenilik kavramı tüketiciler tarafından oldukça olumlu algılanmakta ve pozitif çağrışımlara yol açmaktadır.Tüketiciler ürün alırken yenilikçi bir ürün almayı tercih etmektedirler. Bunun için daha yüksek bir bedel ödemeye razı gözükmektedirler. Yenilikçi işletmelerin marka değeri yükselmektedir ve işletmeler yenilik yaparak imajlarını iyileştirebilmektedirler.Rekabet açsısından dayenilik oldukça önemli bir kavramdır.Yenilikçi olmayan bir işletme her zaman rakiplerini takip etmek zorunda kalacak öncü bir pozisyonda bulunamayacaktır.

Yenilik pazarlama çabalarından bile daha fazla ürün talebi yaratabilmektedir. Reklam ve tanıtım faaliyetleri bile yenilik kadar tüketiciyi etkileyememektedir.Günümüzün artan mesaj bombardımanında tüketiciler reklamdan çok yeniliğe önem vermektedir.

Marka sadakatindede yeniliğin önemi büyüktür. Yenilikçi olarak algılanan bir işletmenin müşterileri firmada yaşanan gelişmeleri daha fazla takip etmekte ve genel olarak ilk tercihlerini müşterileri oldukları yenilikçi işletmelerden yana kullanmaktadırlar. 
Tüketiciler işletmelerin yenilik yaparken daha fazla müşterilere danışmaları gerektiğini düşünmektedir.Yenilik işletmeler tarafından ürünün tasarlanmasından müşterilerin kullanımına kadar geçen bir süreç içerisinde ele alınmalı ve değerlendirilmelidir.Yeni bir ürünü kullanan ve yenilikçi olarak algılanan bir işletmeyi tercih eden tüketiciler kendilerini daha fazla tatmin olmuş hissetmekte, memnuniyet düzeyleri yükselmektedir.

Çalışmadan elde edilen sonuçlara göre işletmelerin büyümeleri ve rekabetçi bir avantaj elde etmeleri için yenilik yapmaları zorunludur.Yenilik işletmeler açısından en büyük tanıtım ve PR faaliyeti olmaktadır.Yenilikçi işletmeler yaptıkları yenilik oranında pazarda kendilerine yer edinmektedirler.Tüketicileri etkilemenin ve onların tatmin oranlarını arttırmanın en etkili yolu yeniliktir. İşletmeler yeniliği yalnızca laboratuar ortamında yapılan bir değişim olarak görmemelidir. Yenilik dinamik bir ortamda, her zaman gerçekleştirilebilecek, bazen hiç beklenmeyen anda ortaya çıkabilecek kadar hızlı gelişen bir süreçtir. Çalışanların tamamı, paydaşlar, müşteriler ne kadar yenilikçi olursa ve yenilik kültürüne işletme ne kadar adapte olabilirse şirket o oranda yenilikçi olabilecektir. Bu açıdan işletmenin yenilikçi bir örgüt iklimine sahip olması gerekmektedir.Yöneticiler yeniliği işletme stratejisinin temeli haline getirmeli, yenilik toplantıları düzenlemeli ve çalışanları yenilik yapmaları konusunda cesaretlendirmelidir.Bu faaliyetleri yapan, kendini küresel rekabetin bir parçası haline getirebilmiş yenilikçi işletmeler pazar paylarını artırarak büyüyecek geri kalan işletmeler ise yeniliğe adapte olamazlarsa yok olma riskiyle karşı karşıya kalacaklardır.

\section{KAYNAKÇA}

Acaray,A., (2007), Küçük Ve Orta Boy İşletmelerde Yenilik Yönetimi: Yenilik Yönetiminde Etkili Olan Örgütsel Yapı Ve Faktörlere İlişkin Bir Araştırma,Yüksek Lisans Tezi, Kocaeli Üniversitesi, Sosyal Bilimler Enstitüsü İşletme Anabilim Dalı.

Arslan, E.T., (2012), İnovasyon ile İç Girişimcilik Etkileşimi: Bilişim 500 Şirketlerinde Bir Araştırma, Doktora Tezi, Süleyman Demirel Üniversitesi, Sosyal Bilimler Enstitüsü İşletme Anabilim Dalı.

Ayyıldız, C., (2012), Bilgi Ve İnovasyon Yönetimi Bağlamında Yayıncılık Endüstrisinde İş Modeli İnovasyonu, Yüksek Lisans Tezi, Yeditepe Üniversitesi, Sosyal Bilimler Enstitüsü İşletme Anabilim Dalı.

Budak, G. (1998), Yenilikçi Yönetimi Yaratıcı Birey, Sistem Yayıncılık, İstanbul.

Bülbül, H. ve Özoğlu,B., (2014), Tüketici Yenilikçiliği Ve Algılanan Riskin Satın Alma Davranışına Etkisi. Erciyes Üniversitesi İktisadi Ve İdari Bilimler Fakültesi Dergisi, Sayı:44, s.43-58.

Çeliktaş, H., (2008), İnovasyon Yönetimi: Çukurova Bölgesinde Faaliyet Gösteren şirketlerde İnovasyon Uygulamalarının Tespitine Yönelik Bir Araştırma, Yüksek Lisans Tezi, Çukurova Üniversitesi, Sosyal Bilimler Enstitüsü İşletme Anabilim Dalı.

Çubukçu, A., (2011), Bir Açık İnovasyon Aracının Sistematik Tasarımı, Ankara.

Demirci, A.E., vd. (2011), Yenilik Yönetimi (Ed: Uzkurt.C. ve Demirci A.E.), TC Anadolu Üniversitesi Yayınları,Eskişehir (ds.anadolu.edu.tr/eKitap/ISY203U.pdf) Erişim Tarihi:15.01.2015

Drucker, P.,(1993), Innovation and Entre-preneurship, HarperCollins Publishers, p.30.

Erdil,O. ve Kitapçı, H., (2007), TKY Araçlarının Kullanımı Ve Firma Yenilikçiliğinin Yeni Ürün Geliştirme Hızı Ve İşletme Performansına Etkisi, Atatürk Üniversitesi,Iktisadi ve İdari Bilimler Dergisi, Cilt: 2 (1), s. 233-245.

Elçi, Ş., (2007), İnovasyon Kalkınmanın Ve Rekabetin Anahtarı, Technopolis Group (2.Baskı)

Goldsmith, R. E. and Foxall, G. R., (2003), The Measurement of İnnovativeness., (Ed: Shavinina.L.V.), The International Handbook On İnnovation, Kidlington: Elsevier Science Ltd, p. 321-330. 
Gökçe, S., (2010), İnovasyon Kavramı Ve İnovasyonun Önemi, Fırat Kalkınma Ajansı.

Günay, Ö., (2007), Kobilerde Yenilik Türlerinin Analizi Ve Yenilik Engellerinin Belirlenmesine Yönelik Bir Araştırma, Yüksek Lisans Tezi, İstanbul Üniversitesi, Sosyal Bilimler Enstitüsü,İşletme Anabilim Dalı.

Güzelsoy, E., (2010), Organizasyonel Öğrenmenin Ürün İnovasyonu Üzerine Etkileri, Yüksek Lisans Tezi, İstanbul Üniversitesi, Fen Bilimleri Enstitüsü, Endüstri Mühendisliği Anabilim Dalı.

Hagedoorn, J. and Cloodt, M., (2003), Measuring Innovative Performance:Is There an Advantage in Using Multiple Indicators?, Research Policy, Vol .32: p.1365-1379.

Hirschman, E. C.,(1980), Innovativeness, Novelty Seeking, and Consumer Creativity. Journal of Consumer Research. 7 (3): 283-295. Retrieved October 27, 2014, from JSTOR database.

Hurley, R.F. and Hult, G.T., (1998), Innovation, Market Orientation, and Organizational Learning: An Integration and Empirical Examination, Journal of Marketing, p. 42-54.

İslamoğlu, A. H., (2003), Tüketici Davranışları, İstanbul: Beta Yayın.

Karaca, Y., (2009),Hizmetlerde İnovasyon Ve Tüketici Algısına Etkisi: Yolcu Taşımacılığı Sektöründe Bir Araştırma, Afyon Kocatepe Üniversitesi Sosyal Bilimler Dergisi, 6 (1), p.195-212.

Karakılıç, N. Y., (2009), Stratejik İttifak Oluşumunda Temel Yeteneklerin Önemi: Tariş Opet Stratejik İttifakı Balanced Scorecard Örneği. Balıkesir Üniversitesi Sosyal Bilimler Enstitüsü Dergisi 12 (21), p. 200-214.

Kotler, P., (2000), Pazarlama Yönetimi, (Çev:Muallimoğlu, N.), İstanbul: Beta Yayın.

Nasution, R. A. and Garnida, V, (2010), A Review of the Three Streams of Consumer Innovativeness, Technology Management for Global Economic Growth (PICMET), 2010 Proceedings of PICMET '10, 1-11. Retrieved October 2014, from IEEE Xplore database.

OECD (2006), Oslo Kılavuzu, TÜBiTAK, (3.Baskı)

Özçiftci, V.ve Sarıçay, H.,(2014), İşletmelerde Yenilikçilik Faaliyetlerinin İncelenmesi, Atatürk Üniversitesi Sosyal Bilimler Enstitüsü Dergisi, 18 (1), p. 387-404.

Özdaşlı, K., (2002), Bilgi Toplumu İşletmelerinde Yenilikçi Özellikler : Göller Bölgesi (Isparta Ve Burdur) İşletmelerinde Bir Araştırma, Yüksek Lisan Tezi, Süleyman Demirel Üniversitesi Sosyal Bilimler Enstitüsü İşletme Anabilim Dalı.

Özdamar, K. (1999), SPSS ile Biyoistatistik (3. Baskı). Eskişehir: Kaan Kitabevi.

Öztürk, E., Mesci, M., ve Kılınç, İ., (2013), Yenilik Faaliyetlerinin İşletme Performansına Etkisi: Yat Limanları Üzerine Bir Değerlendirme, Girişimcilik ve Kalkınma Dergisi, 8(2), s. 97-118.

Sarıçay, H., (2012), İşletmelerde Yenilikçilik Faaliyetlerinin İncelenmesi, Yüksek Lisans Tezi, Aksaray Üniversitesi Sosyal Bilimler Enstitüsü İşletme Anabilim Dalı.

Tedarik Zincirinde İnovasyon Avantajı, aralık 2004, Dergil (lojistik ve tedarik zinciri dergisi; http://www.dergil.com/tr/dergi/aralik-2004/tedarik-zincirinde-inovasyon-avantaji/44.aspx)Erişim Tarihi: 29.04.2015

Tellis, G. J. , Yin, E. and Bell, S., (2009), Global Consumer Innovativeness: Cross-Country Differences and Demographic Commonalities. Journal of International Marketing. $17 \quad(2)$, $1-22$. (http://gtellis.net/Publications/globalconsumer.pdf) Erişim Tarihi: 10.09.2014

Terzioğlu, M., Avcı. M., Ve Gökovalı, U., (2008), İşletmelerde Yenilik Yeteneği: Denizli Tekstil Ve Hazır Giyim Sektörü Örneği, Çukurova Üniversitesi Sosyal Bilimler Enstitüsü Dergisi, Cilt 17 (3), s.377-388.

Trott, P.,(2005), Innovation Management and New Product Development, Pearson Education Limited

Uzkurt, C., (2010), İnovasyon Yönetimi: İnovasyon Nedir, Nasıl Yapılır ve Nasıl Pazarlanır?, Ankara Sanayi Odası Yayın Organı (Temmuz-Ağustos).

Venkatraman, N., And Ramanujam, V.,(1986), "Measurement of Business Performance in Strategy Research: A comparison of Approaches," The Academy of Management Review, 11(4), p. 801-814. 
Yavuz,Ç., (2010), İşletmelerde İnovasyon-Performans İlişkisinin İncelenmesine Dönük Bir Çalışma, Girişimcilik Ve Kalkınma Dergisi (Journal Of Entrepreneurship And Development) 5 (2), s. 143-173.

Yücel, H., (2009), Şirketlerin Karlı Büyümelerinde İnovasyonun Önemi. Yüksek Lisans Tezi, Maltepe Üniversitesi, Sosyal Bilimler Enstitüsü İşletme Anabilim Dalı. 